\title{
PEMBELAJARAN MATERI EKOSISTEM DENGAN JIGSA $W$ MELALUI HYPERMEDIA DAN MODUL DITINJAU DARI KEMAMPUAN MEMORI DAN INTERAKSI SOSIAL SISWA
}

\author{
Tri Lukitaningsih \\ SMP Negeri I Paron \\ trilukita@gmail.com
}

\begin{abstract}
The objectives of the research were to know: 1) the effect of Jigsaw learning through Hypermedia and module toward student's achievement; 2) the effect of high and low memory ability toward student's achievement; 3) the effect of high and low social interaction toward student's achievement; 4) interaction between learning media and memory ability toward student's achievement; 5) interaction between learning media and social interaction toward the student's achievement; 6) interaction between memory ability and student social interaction toward the student's achievement; 7) interaction between learning media and memory ability and student social interaction toward the student's achievement. The research sample was determined by random cluster sampling technique that consists of two classes. Data collection techniques for achievement tests and memory skills, social interaction questionnaire for. Anova test hypotheses using $2 \times 2 \times 2$ factorial design with the help of software Minitab 15.1.2. Based on the research were concluded : 1) There was an effect of with hypermedia and module toward the student's achievement. 2) There was no effect of memory ability to ward student's achievement. 3) There was an effect of social interaction toward student's achievement. 4) There was no interaction between learning media and student's memory ability toward student's achievement. 5) There was no interaction between learning media and social interaction toward student's achievement. 6) There was no interactoin memory ability and social interaction toward student's achievement. 7) There was no interaction memory ability, social interaction, and learning media toward student's achievement .
\end{abstract}

Keywords: jigsaw, memory ability, social interaction, hypermedia, module.

\section{PENDAHULUAN}

Pencapaian tujuan pendidikan sebagian besar ditentukan oleh keberhasilan proses belajar mengajar di kelas. Keberhasilan proses belajar mengajar di kelas dipengaruhi oleh berbagai faktor. Masalah utama dalam pembelajaran Biologi adalah bagaimana menghubungkan fakta yang pernah dilihat dan dialami siswa dalam kehidupan seharihari dengan konsep Biologi, sehingga menjadikan pengetahuan yang bermakna dalam benak siswa. Selama ini pemahaman siswa hanya terpaku pada penjabaran konsep Biologi yang ada dalam buku, tanpa memahami apa dan bagaimana makna yang terkandung dalam konsep tersebut.

Semenjak diberlakukannya Kurikulum Tingkat Satuan Pendidikan (KTSP) yang merupakan kurikulum operasional yang disusun dan dilaksanakan oleh masing-masing satuan pendidikan yang intinya memberikan peluang kepada tiaptiap satuan pendidikan untuk menyusun sebuah kurikulum yang disesuaikan dengan kondisi sekolah masing-masing. Kurikulum dikembangkan berdasarkan prinsip bahwa peserta didik memiliki posisi sentral untuk mengembangkan kompetensinya agar menjadi manusia yang beriman dan bertakwa kepada Tuhan Yang Maha Esa, berakhlak mulia, sehat, berilmu, cakap, kreatif, mandiri dan menjadi warga negara yang demokratis serta bertanggung jawab. Utamanya pendidik yang dalam hal ini merupakan satu komponen yang langsung berperan dalam proses pembelajaran dituntut untuk dapat mengembangkan pembelajaran yang 
inovatif (Uno, 2007). Hal ini akan mengubah paradigma dalam proses pendidikan khususnya proses pembalajaran.

Perubahan proses pembelajaran lebih menekankan dan menjadi lebih mementingkan peran serta didik dan karakteristik sumber daya yang ada pada tiap-tiap satuan pendidikan. Pembelajaran berpusat pada siswa, oleh karenannya siswalah yang diharapkan dapat berperan aktif dalam mengeksplorasi dan menginterprestasikan pengetahuan dan permasalahan baru yang dibandingkan, dikombinasikan, dan dianalisa dengan pengetahuan dasar yang telah dimiliki oleh peserta didik. Proses pembelajaran lebih diutamakan daripada hasil yang diperoleh. pembelajaran yang berpusat pada siswa (student centered) cenderung lebih memperlihatkan paradigma pendidikan saat ini sebagaimana yang terkandung dalam Kurikulum Tingkat Satuan Pendidikan.

Keberhasilan pembelajaran Biologi tidak luput dari berbagai pendukung pembelajaran baik guru, media pembelajaran, sarana dan prasarana, selain itu juga dari diri siswa sendiri yang berupa kemampuan memori dan interaksi sosial yang sangat heterogen. Seiring dengan heterogennya kemampuan memori serta interaksi sosial siswa tersebut maka untuk pencapaian prestasi belajar, guru memerlukan inovasi pembelajaran. Untuk mendukung keberhasilan pembelajaran, dalam penelitian mencoba menggunakan sebuah metode pembelajaran yang dipadu dengan media pembelajaran. Dengan hal diharapkan anak dapat menentukan sendiri keinginan mereka cara belajar yang menarik hati dan memotivasi mereka untuk belajar. Metode pembelajaran dan media pembelajaran yang dimungkinkan dapat mempengaruhi prestasi belajar Biologi yaitu metode pembelajaran kooperatif Jigsaw dengan Modul dan Hypermedia.

Kemampuan memori atau ingatan secara sempit dapat diartikan sebagai kemampuan untuk menerima atau memasukkan kesan-kesan, menyimpan kesan-kesan itu dan kemudian mengeluarkan kembali kesan-kesan yang pernah diterima (Walgito, 1985). Mengingat adalah suatu proses pengolahan informasi yang telah dipelajari atau diperoleh dari stimulus yang dapat dipelihara dan diperoleh kembali di masa mendatang. Seseorang berkemampuan memori yang sangat tinggi memiliki ciriciri sebagai berikut: 1) proses encoding yang majemuk dan bermakna; 2) memiliki banyak cue dengan asosiasi tinggi; banyak latihan. Memori akan lebih baik jika sesuatu yang dipelajari dengan berulangulang walaupun dengan sesi yang cukup pendek dari pada sesi atau waktu yang lebih lama. Kenyataan di lapangan masih banyak ditemukan anak yang memiliki kemampuan memori tinggi yang tidak didukung oleh sarana dan prasarana sekolah yang memadai, sehingga tidak memberikan kesempatan kepada mereka untuk dapat lebih berkembang. Kemampuan guru dalam pengelolaan kelas, penggunaan model dan metode pembelajaran yang digunakan juga dapat merangsang kemampuan memori siswa. Selain itu memori akan lebih baik apabila untuk memahami atau mengingat suatu materi dengan berbagai cara misalnya segi visual dan audio lebih baik daripada hanya satu saja.

Interaksi sosial siswa memiliki peran penting dalam kegiatan pembelajaran. Menurut Vygostky belajar adalah sebuah proses yang melibatkan dua eleman penting yaitu, 1) belajar merupakan proses secara Biologi sebagai proses dasar; 2) belajar merupakan proses psikososial sebagai proses yang lebih tinggi esensinya berkaitan dengan lingkungan sosial budaya. Thibaut dan Kelley dalam Ali (2004) mendefinisikan interaksi sebagai peristiwa saling mempengaruhi satu sama lain ketika dua orang atau lebih hadir bersama, mereka menciptakan suatu hasil satu sama lain atau berkomunikasi satu sama lain. Jadi dalam kasus interaksi, tindakan setiap orang bertujuan untuk mempengaruhi individu lain. Menurut Bonner dalam Ali (2004) interaksi sosial 
merupakan suatu hubungan antara dua orang atau lebih individu, dimana kelakuan individu mempengaruhi, mengubah atau mempengaruhi individu lain atau sebaliknya. Pemenuhan prestasi belajar yang maksimal dalam pembelajaran diperlukan pula kerjasama antara siswa dengan siswa, antara siswa dengan guru, antara siswa dengan lingkungan sekolah, dan antara siswa dengan sarana dan prasarana sekolah. Interaksi atau hubungan antara siswa dengan teman, guru, lingkungan sekolah, dengan sarana dan prasarana dapat dikembangkan melalui berbagai metode dan model pembelajaran.

Jigsaw adalah teknik mengajar dikembangkan oleh Eliliot Aroson dalam Lie (2002). Jigsaw yaitu teknik mengajar dimana siswa dalam pembelajaran berlangsung diharapkan bekerja bersama sesama siswa dalam suasana gotong royong dan mempunyai banyak kesempatan untuk mengolah informasi dan meningkatkan keterampilan berkomunikasi. Pembelajaran Kooperatif tipe Jigsaw karena pembelajaran menurut Kemal Deymus dalam jurnalnya bahwa kooperatif Jigsaw dapat membuat siswa bertanggung jawab terhadap materi pembelajaran ke kelompok tersebut.

Pembelajaran kooperatif merupakan suatu model pengajaran dimana siswa belajar dalam kelompok-kelompok kecil yang memiliki tingkat kemampuan berbeda. Proses penyelesaikan tugas kelompok, setiap anggota saling bekerja sama dan membantu untuk memahami suatu bahan pembelajaran. Belajar belum selesai jika salah satu teman dalam kelompok belum menguasai bahan pembelajaran. Maka dengan penerapan pembelajaran kooperatif diharapkan interaksi sosial siswa akan tumbuh, karena siswa dalam pembelajaran kooperatif jigsaw siswa dikelompokkan untuk saling bekerjasama dan saling membantu dalam memahami bahan atau materi pelajaran.

$$
\text { Anitah (2009) hypermedia, }
$$

merupakan media yang memiliki komposisi materi-materi yang tidak berurutan. Hypermedia mengacu pada software komputer yang menggunakan unsur-unsur teks, grafis, video dan audio yang dihubungkan dengan cara yang dapat mempermudah pemakai untuk beralih ke suatu informasi. Pemakai dapat memilih cara yang unik sesuai gaya berpikir dan cara memproses informasinya sendiri.

Modul adalah suatu cara pengorganisasian materi pelajaran yang memperhatikan fungsi pendidikan (Santyasa, 2009).Strategi pengorganisasian materi pembelajaran mengandung squencing yang mengacu pada pembuatan urutan penyajian materi pelajaran dan synthesizing yang mengacu pada upaya untuk menunjukkan kepada pembelajar keterkaitan antara fakta, konsep, prosedur dan prinsip yang terkandung dalam materi pembelajaran. Materi yang diajarkan adalah ekosistem. Materi ini banyak hal yang harus diinformasikan kepada anak, bersifat cukup abstrak, agak sulit dipahami, namun bisa disampaikan dengan strategi belajar yang bervariasi. Guru, dalam hal ini berusaha untuk mencover keinginan anak tersebut dengan menyerahkan kepada mereka cara belajar yang mereka inginkan, kemudian guru berusaha membawa dan membimbing siswa dalam kondisi yang diinginkan, dengan harapan belajar sesuai dengan keinginan siswa akan mampu mendorong dan mempercepat pemahaman siswa terhadap materi pelajaran. Ini akan diindikasikan dengan tingginya kemampuan memori dan interaksi sosial siswa akan berpengaruh terhadap hasil prestasi belajar pada ulangan harian siswa pada materi ekosistem.

Berdasarkan pertimbangan di atas bahwa teori bejalar yang mendukung Peaget siswa langsung dapat berinteraksi dengan materi ekosistem dari media pembelajaran yaitu hypermedia dan modul. Penggunaan Hypermedia dan modul karakteristik materi ekosistem dapat diamati oleh siswa secara langsung. Pengamatan langsung siswa sudah memiliki bekal waktu masuk kelas 
sehingga siswa dapat belajar sendiri secara kelompok dengan pembelajaran kooperatif Jigsaw. Pembelajaran Jigsaw dapat mewujudkan pembelajaran yang aktif, kreatif, efektif dan menyenangkan. Belajar kooperatif jigsaw memberikan kesempatan pada siswa untuk saling berinteraksi. Siswa tidak hanya mempelajari materi yang diberikan, tetapi mereka juga harus siap memberikan dan mengajarkan materi tersebut pada anggota kelompoknya yang lain, sehingga pengetahuannya jadi bertambah. Keunggulan kooperatif tipe jigsaw meningkatkan rasa tanggung jawab siswa terhadap pembelajarannya sendiri dan juga pembelajaran orang lain. Meningkatkan bekerja sama secara kooperatif untuk mempelajari materi yang ditugaskan.

Sistem pembelajaran modern saat ini, siswa tidak hanya sebagai komunikan atau penerima pesan, bisa juga siswa sebagai komunikator atau penyampai pesan. Dalam kondisi seperti ini akan terjadi komunikasi dua arah (two way traffic communication) bahkan komunikasi banyak arah (multi way traffic communication). Dalam bentuk komunikasi pembelajaran sangat dibutuhkan peran media untuk lebih meningkatkan tingkat keefektifan pencapaian tujuan/kompetensi. Sistem pembelajaran didalamnya mengandung komponen yang saling berkaitan erat untuk mencapai suatu tujuan yang meliputi: tujuan, materi, metode, media dan evaluasi (Susilana,2007)

\section{METODE}

Penelitian dilakukan di SMPN 2 Paron Kabupaten Ngawi. Waktu penelitian adalah semester genap tahun pelajaran 2011/2012. Sampel dalam penelitian ini adalah siswa kelas VII A dan VII B sebanyak 72 siswa. Teknik pengambilan sampel yang digunakan dalam penelitian ini adalah cluster random sampling, yaitu teknik pengambilan sampel secara acak. Penelitian ini bersifat eksperimental karena hasil penelitian ini akan menegaskan perbedaan variabel yang diteliti yaitu model pembelajaran Jigsaw dengan hypermedia dan modul. Pada penelitian ini kemampuan memori siswa dibedakan kemampuan memori tinggi dan rendah, dan interaksi sosial dibedakan Interaksi sosial tinggi dan rendah, untuk model jigsaw dengan hypermedia dan modul. Rancangan desain yang digunakan adalah

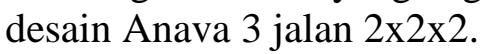

Uji persyaratan analisis dengan menggunakan uji normalitas digunakan untuk mengetahui apakah sampel penelitian berasal dari populasi yang berdistribusi normal atau tidak. Uji normalitas ini menggunakan software minitab 15.1.2 (Pribadi, 2008) dengan hipotesis sebagai berikut :

$\mathrm{H}_{0}=$ Sampel tidak berasal dari populasi berdistribusi normal

$\mathrm{H}_{1}=$ Sampel berasal dari populasi berdistribusi normal

Uji homogenitas digunakan untuk menguji apakah sampel berasal dari populasi yang homogen atau tidak. Uji yang digunakan dalam penelitian ini yaitu data prestasi belajar interaksi sosial, prestasi belajar versus kemampuan memori, dan prestasi belajar versus media (hypermedia dan modul) yang digunakan Tes-F dan Tes-Levene, dengan hipotesis sebagai berikut :

$\mathrm{H}_{0}=$ sampel dari populasi tidak homogen

$\mathrm{H}_{1}=$ sampel dari populasi homogen

Hipotesis dalam penelitian ini akan diuji dengan menggunakan metode analisis variansi tiga jalan dengan isi sel tidak sama apabila $p$-value lebih kecil daripada alpha maka dilanjutkan dengan uji lanjut analisis variansi yaitu uji lanjut hipotesis.

\section{HASIL DAN PEMBAHASAN}

Berdasarkan tabel 1 rangkuman $p$ value uji hipotesis aspek kognitif di dapat $p$-value $=0,33$ jadi $p$-value $<\alpha$ hal ini berarti terdapat perbedaan pembelajaran kooperatif tipe jigsaw dengan hypermedia dan modul. Hasil prestasi belajar biologi materi pokok ekosistem menunjukkan bahwa rata-rata 67,39 pada kelompok hypermedia sedangkan pada kelompok modul memiliki rata-rata sebesar 64,39. Apabila dibandingkan dari kedua media 
yang digunakan dalam pembelajaran materi pokok ekosistem dengan melihat rata-rata prestasi belajar pada pembelajaran kooperatif tipe jigsaw memberikan pengaruh yang lebih baik daripada menggunakan modul.

Tabel 1. Rangkuman $p$-value Uji Hipotesis Aspek Kognitif

\begin{tabular}{ccl}
\hline Hipotesis & \multicolumn{1}{c}{$\boldsymbol{p}$-value } & \multicolumn{1}{c}{ Keputusan } \\
\hline 1 & $0,033(\mathrm{p}<\alpha)$ & $\mathrm{H}_{0} 1$ ditolak \\
2 & $0,900(\mathrm{p}>\alpha)$ & $\mathrm{H}_{0} 2$ diterima \\
3 & $0,025(\mathrm{p}<\alpha)$ & $\mathrm{H}_{0} 3$ ditolak \\
4 & $0,067(\mathrm{p}>\alpha)$ & $\mathrm{H}_{0} 4$ diterima \\
5 & $0,098(\mathrm{p}>\alpha)$ & $\mathrm{H}_{0} 5$ diterima \\
6 & $0,617(\mathrm{p}>\alpha)$ & $\mathrm{H}_{0} 6$ diterima \\
7 & $0,138(\mathrm{p}>\alpha)$ & $\mathrm{H}_{0} 7$ diterima \\
\hline
\end{tabular}

Pembelajaran materi pokok ekosistem pada siswa kelas VII SMPN 2 Paron, Kabupaten Ngawi pada saat dilaksanakannya penelitian ini menunjukkan siswa yang belajar kooperatif dengan menggunakan hypermedia terlihat tampak lebih antusias dan bersemangat, hal tersebut dikarenakan siswa merasakan suasana baru dalam belajar yaitu dengan memanfaatkan media elektronik dalam penyampaian materi. Siswa dapat melihat gambaran secara langsung interaksi antara komponen dalam ekosistem. Sedangkan kelompok siswa yang belajar kooperatif dengan modul secara hasil akhir setelah diberikan post test yang berupa test prestasi belajar ekosistem secara tidak signifikan berbeda dengan pembelajaran dengan hypermedia, namun pada proses pembelajaran siswa pada kelompom hypermedia tampak lebih menikmati proses pembelajaran dibandingkan dengan siswa pada kelompok belajar dengan menggunakan modul.

Anitah

(2009) hypermedia, merupakan media yang memiliki komposisi materi-materi yang tidak berurutan. Hypermedia mengacu pada software komputer yang menggunakan unsur-unsur teks, grafis, video dan audio yang dihubungkan dengan cara yang dapat mempermudah pemakai untuk beralih ke suatu informasi. Pemakai dapat memilih cara yang unik sesuai gaya berpikir dan cara memproses informasinya sendiri. Hypermedia siswa cenderung lebih aktif belajar dan lebih senang mengikuti pembelajaran. Berdasarkan hasil penelitian tersebut maka pembelajaran yang menyenangkan siswa yang membuat siswa terutama siswa sekolah menengah pertama merasakan kenyamanan belajar akan memberikan pengarauh yang lebih baik, pembelajaran tersebut terlaksana pada proses pembelajaran kooperatif tipe jigsaw dengan hypermedia dan modul.

Pada hipotesis II berdasarkan hasil uji hipotesis dengan analisis variansi didapat bahwa $p$-value $=0,900$ maka $p$ > $\alpha$, hal ini berarti tidak terdapat perbedaan antara siswa yang memiliki kemampuan memori tinggi dengan siswa yang memiliki kemapuan memori rendah. Namun hal ini bukan berarti tidak ada perbedaan sama sekali, berdasarkan hasil uji masingmasing kriteria tiap sel didapat bahwa siswa dengan kemampuan memori tinggi mempunyai rata-rata lebih tinggi daripada siswa yang memiliki kemampuan memori rendah baik pada pada kelompok hypermedia maupun modul. Hal tersebut tampak pada hasil rata-rata prestasi belajar pada tabel yaitu pada kelompok hypermedia kemampuan memori tinggi dan rendah secara berturut-turut adalah 78 dan 67,33, sedangkan pada kelompok modul rata-rata kemampuan memori tinggi dan rendah secara berturut-turut adalah 69,13 dan 67,29.

Mata pembelajaran ekosistem syarat yang harus dimiliki siswa adalah tentang konsep makhluk hidup yang meliputi ciriciri, jenis, dan karkateristik makhluk hidup. Berdasarkan hasil uji hipotesis didapat harga pada $p$-value $=0,025(\mathrm{p}<\alpha)$ maka dinyatakan $\mathrm{H}_{0} 3$ ditolak, hal ini mempunyai arti bahwa terdapat pengaruh perbedaan antara siswa yang memiliki interaksi sosial tinggi dengan siswa yang memiliki interaksi sosial rendah terhadap prestasi belajar biologi. Interaksi sosial dalam belajar biologi dengan pembelajaran kooperatif akan menentukan kelancaran 
siswa dalam memhami materi yang sedang dipelajarinya.

Berdasarkan hasil uji lanjut analisis variansi dapat dilihat bahwa siswa dalam kategori interaksi sosial rendah mempunyai nilai rata-rata lebih tinggi daripada siswa dalam kategori interaksi sosial tinggi. Keadaan yang terjadi dalam pendidikan prestasi belajar yang lebih baik biasanya didominasi oleh siswa yang rendah interaksi sosialnya, karena karakteristik siswa tersebut cenderung lebih suka belajar daripada bergaul dengan teman-temannya. Hal tersebut tampak ketika siswa yang termasuk dalam kategori interaksi sosial tinggi lebih suka bercanda pada saat jam istirahat sekolah sedangkan siswa dalam kategori interaksi sosialnya rendah lebih cenderung suka menghabiskan waktu belajar di perpustakaan sekolah.

Berdasarkan keputusan uji harga pada $p$-value $=0,067$ atau $(\mathrm{p}>\alpha)$ maka dinyatakan $\mathrm{H}_{0} 4$ diterima, hal ini mempunyai arti bahwa tidak terdapat interaksi antara media pembelajaran dengan kemampuan memori siswa terhadap prestasi belajar biologi. Pada penelitian ini tidak ditemukan pengaruh bersama yang signifikan antara kemapuan memori tinggi dan rendah dengan penggunaan media terhadap prestasi belajar biologi. Pengaruh yang diberikan kemampuan memori tinggi merupakan pengaruh yang berdiri sendiri dan tidak berhubungan dengan kemampuan memori rendah. Begitu pula sebaliknya, pengaruh yang diberikan oleh kemampuan memori rendah terhadap prestasi belajar biologi merupakan pengaruh yang berdiri sendiri dan tidak berhubungan dengan kemapuan memori tinggi. Dua variabel yang diteliti tidak menghasilkan kombinasi efek yang signifikan, sehingga disimpulkan tidak ada interaksi yang signifikan antara kemampuan memori tinggi dan rendah. Namun hal ini bukan berarti tidak ada interaksi sama sekali.

Berdasarkan tabel 1 dapat diketahui bahwa rata-rata yang dicapai oleh siswa pada kelompok hypermedia dengan kemampuan memori tinggi dan rendah berturut-turut adalah adalah 66,09 dan 66,69 sedangkan pada kelompok modul rata-rata prestasi belajar pada kategori kemampuan memori tinggi dan rendah berturut-turut adalah adalah 66,11 dan 70,10. Berdasarkan data-data tersebut maka dapat diketahui bahwa siswa dengan kemampuan memori tinggi maupun rendah lebih cocok apabila belajar ekosistem dengan menggunakan modul daripada hypermedia.

Keputusan uji hipotesis harga pada $p$-value $=0,098$ atau $(\mathrm{p}>\alpha)$ maka dinyatakan $\mathrm{H}_{0} 5$ diterima, hal ini mempunyai arti bahwa tidak terdapat interaksi antara media pembelajaran dengan interaksi sosial tinggi dan terhadap prestasi belajar biologi. Penelitian ini ditemukan tidak ada pengaruh yang signifikan antara interaksi sosial dengan media pembelajaran terhadap prestasi belajar Biologi pada materi pokok ekosistem. Pengaruh yang diberikan interaksi sosial terhadap prestasi belajar biologi adalah pengaruh yang berdiri sendiri dan tidak berhubungan dengan media pembelajaran, dan begitu juga sebaliknya pengaruh yang diberikan media pembelajaran terhadap prestasi belajar adalah pengaruh yang berdiri sendiri dan tidak berhubungan dengan interaksi sosial. Dua variabel tersebut tidak menghasilkan kombinasi efek yang signifikan, sehingga disimpulkan tidak ada interaksi yang signifikan antara media pembelajaran dengan interaksi sosial. Namun demikian bukan berarti tidak ada interaksi sama sekali antara interaksi sosial dengan dengan hypermedia dan modul terhadap prestasi belajar Biologi.

Melihat data pada tabel 1 maka dapat dilihat bahwa prestasi belajar rata-rata dengan interaksi sosial tinggi dan rendah pada hypermedia berturut-turut adalah adalah 70 dan 67,33 sedangkan nilai ratarata interaksi sosial tinggi dan rendah pada kelompok modul berturut-turut 69,13 dan 67,29. Berdasarkan data-data pada penelitian ini, ditemukan bahwa siswa dengan interaksi sosial tinggi cenderung 
lebih cocok belajar ekosistem dengan menggunakan htpermedia sedangkan siswa dengan interaksi sosial rendah cenderung lebih cocok belajar dengan kedua media tersebut yaitu hypermedia maupun modul.

Berdasarkan keputusan uji hipotesis harga pada $p$-value $=0,617$ atau $(\mathrm{p}>\alpha)$ maka dinyatakan $\mathrm{H}_{0} 6$ diterima, hal ini mempunyai arti bahwa tidak terdapat interaksi antara kemampuan memori dengan interaksi sosial siswa terhadap prestasi belajar biologi. Didalam penelitian ini tidak ditemukan pengaruh bersama yang signifikan antara kemampuan memori dengan interaksi sosial terhadap prestasi belajar. Pengaruh yang diberikan kemapuan memori terhadap prestasi belajar merupakan yang berdiri sendiri dan tidak berhubungan dengan kemampuan meori. Begitu pula sebaliknya, pengaruh yang diberikan oleh interaksi sosial terhadap prestasi belajar merupakan prestasi yang berdiri sendiri dan tidak berhubungan dengan kemampuan memori. Dua variabel yang diteliti tidak menghasilkan kombinasi efek yang signifikan, sehingga disimpulkan tidak ada interaksi yang signifikan antara kemampuan memoridengan interaksi sosial.

Pada hipotesis ke-7 dari tabel 1 harga pada $p$-value $=0,138$ atau $(\mathrm{p}>\alpha)$ maka dinyatakan $\mathrm{H}_{0} 7$ diterima, hal ini mempunyai arti bahwa tidak terdapat interaksi antara kemampuan memori dan interaksi sosial dengan media pembelajaran hypermedia dan modul siswa tehadap prestasi belajar biologi. Hipotesis 7 merupakan hipoetsis untuk interaksi orde dua (second mark interaction) yang merupakan interaksi antara sepasang variabel dengan variabel ketiga. Interaksi antara sepasang variabel yang dikenal dengan interaksi orde pertama (first rank interaction) terdapat pada hipotesis 4, 5 dan 6. Berdasarkan pengujian hipotesis 4,5, dan 6 tidak terdapat interaksi yang signifikan untuk interaksi orde pertama, maka tentunya interaksi orde kedua juga tidak ada.

\section{SIMPULAN}

Berdasarkan hasil pengujian hipotesis dan pembahasan dapat disimpulkan terdapat perbedaan pengaruh pembelajaran kooperatif tipe jigsaw dengan hypermedia dan modul terhadap prestasi belajar biologi materi pokok ekosistem. Pembelajaran dengan hypermedia memberikan pengaruh positif terhadap prestasi belajar dibandingkan dengan modul. Oleh karena itu, pembelajaran dengan menerapkan hypermedia sebagai media dalam belajar ekosistem cenderung lebih baik daripada menggunkan modul.

Kemampuan memori tidak memberikan pengaruh perbedaan yang signifikan. Secara umum, prestasi belajar dari kemampuan memori siswa yang masuk kategori tinggi dan rendah tidak jauh berbeda. Namun, berdasarkan ratarata prestasi belajar, siswa yang memiliki kemampuan memori tinggi mempunyai pengaruh positif terhadap prestasi belajar daripada siswa yang memiliki kemampuan memori rendah. Jadi siswa yang memiliki rata-rata skor kemampuan memori tinggi mendapat prestasi belajar yang yang lebih baik daripada siswa yang memiliki skor prestasi pada kemapuan memori kategori rendah.

Interaksi sosial mempunyai pengaruh yang signifikan terhadap prestasi belajar biologi. Berdasarkan hasil uji lanjut variansi diketahui bahwa interaksi sosial rendah memberikan pengaruh positif yang signifikan terhadap prestasi belajar biologi. Jadi siswa yang memiliki interaksi sosial rendah mencapai prestasi belajar yang lebih tinggi dibandingkan siswa yang memiliki interaksi sosial tinggi. Sebaliknya, hasil uji lanjut variansi juga diketahui bahwa interaksi sosial tinggi memberikan pengaruh negatif yang signifikan terhadap prestasi belajar biologi, jadi siswa yang memiliki interaksi sosial tinggi cenderung mencapai prestasi belajar biologi yang rendah. 


\begin{tabular}{ll}
\hline Kemampuan memori tidak & interaksi sosial didapatkan bahwa rata-rata \\
mempunyai pengaruh bersama dengan & $\begin{array}{l}\text { prestasi belajar paling tinggi didapatkan } \\
\text { oleh siswa yang memiliki kemampuan }\end{array}$ \\
media pembelajaran hypermedia dan & memori tinggi dan interaksi sosial rendah, \\
modul terhadap prestasi belajar biologi. & namun prestasi terendah rata-rata dimiliki \\
Pengaruh bersama atau interaksi yang & oleh siswa yang memilki kemampuan \\
diharapkan terbangun antara kemampuan & memori rendah dan interaksi sosial tinggi. \\
memori dengan media pembelajaran & Kemampuan memori, interaksi \\
hypermedia dan modul ternyata tidak & sosial, dan media pembelajaran \\
signifikan. Namun, berdasarkan analisis & hypermedia dan modul juga tidak \\
interaksi kemampuan memori dengan & memberikan pengaruh bersama terhadap \\
media didapatkan bahwa siswa dengan & prestasi belajar biologi. \\
kemampuan memori tinggi maupun rendah &
\end{tabular}
dengan menggunakan modul daripada hypermedia.

Interaksi sosial tidak mempunyai pengaruh bersama dengan media pembelajaran hypermedia dan modul terhadap prestasi belajar biologi. Pengaruh bersama atau interaksi yang diharapkan terbangun antara kemapuan awal dengan media pembelajaran hypermedia dan modul ternyata tidak signifikan. Namun, berdasarkan analisis interaksi interaksi sosial dengan media didapatkan ditemukan bahwa siswa dengan interaksi sosial tinggi cenderung lebih cocok belajar ekosistem dengan menggunakan hypermedia sedangkan siswa dengan interaksi sosial rendah cenderung lebih cocok belajar dengan kedua media tersebut yaitu hypermedia maupun modul.

Kemampuan memori dengan interaksi sosial tidak memberikan pengaruh bersama terhadap prestasi belajar biologi. Berdasarkan analisis interaksi kemampuan memori dengan

\section{DAFTAR PUSTAKA}

Ali, M. dan Asrori, M. 2004. Psikologi Remaja. Jakarta: Bumi Aksara.

Lie, A. 2002. Cooperative Learning Mempraktikan Cooperative Lerning di Ruang-Ruang Kelas. Jakarta: Grasindo

Uno, H.B. 2007. Model Pembelajaran Menciptakan Proses Belajar Mengajar yang Kreatif dan Efektif. Gorontalo: Bumi Aksara.

Pribadi, M. 2008. Minitab 15 Uji T hingga Anova. Surakarta : PPS UNS

Anitah, S. 2009. Media Pembelajaran. Solo: UNS Press.

Winata Putra. 2006. Model-model Pembelajaran Inovatif. Jakarta: Depdiknas

Santyasa, W. 2009. Metode Penelitian Pengembangan dan Teori Pengembangan Modul. Bali. Universitas Pendidikan Ganesha. 